\title{
Идеологические установки советского государства по отношению к Русской православной церкви и их реализация в период подготовки и проведения VI Всемирного фестиваля молодежи и студентов 1957 года
}

\author{
Н.В. Остроухова \\ Белгородский государственный национальный исследовательский университет, \\ Россия, 308015, г. Белгород, ул. Победы, 85 \\ E-mail:108805@bsu.edu.ru
}

\begin{abstract}
Аннотация
В статье проанализированы особенности практической реализации идеологических установок советского государства при подготовке и проведении VI Всемирного фестиваля молодежи и студентов, проходившего в июле-августе 1957 года. Это событие состоялось в условиях политики «десталинизации», развернутой Н.С. Хрущевым, и, как следствие, относительной неопределенности состояния государственно-церковных отношений. Анализ реализуемых органами государственной власти методов и средств идеологической подготовки и контроля участников принимающей стороны важен не только для понимания сложившегося подчиненного статуса Русской православной церкви в государственно-церковных отношениях. Подготовленные для духовенства директивы, трактовавшие вопросы устройства и положения Русской православной церкви, свободы совести, значения религии как пережитка капитализма в СССР, свидетельствовали о начале нового витка богоборческой политики. При этом ожидаемые, но провокационные для власти вопросы об истинном положении Русской православной церкви в СССР, а также настойчивые высказывания иностранных гостей о конкурентоспособности православной веры в условиях существующей государственной идеологии коммунизма могли послужить катализатором антирелигиозных гонений, развернутых советской властью в 1958 году.
\end{abstract}

Ключевые слова: советское государство, Русская Православная Церковь, духовенство, верующие, государственно-церковные отношения, антирелигиозная политика, VI Всемирный фестиваль молодежи и студентов.

Для цитирования: Остроухова Н.В. 2021. Идеологические установки советского государства по отношению к Русской православной церкви и их реализация в период подготовки и проведения VI Всемирного фестиваля молодежи и студентов 1957 года. Via in tempore. История. Политология, 48 (1): 188-197. DOI: 10.52575/2687-0967-2021-48-1-188-197.

\section{The ideological instructions of the Soviet state in relationship to the Russian Orthodox Church and their implementation during the preparation and holding of the VI World Festival of Youth and Students in 1957}

\author{
Natalya V. Ostroukhova \\ Belgorod National Research University, \\ 85 Pobeda St., Belgorod, 308015, Russia \\ E-mail: 108805@bsu.edu.ru
}

\begin{abstract}
The article analyzes the features of the practical implementation of the ideological guidelines of the Soviet state during the preparation and holding of the VI World Festival of Youth and Students,
\end{abstract}


held in July-August 1957. This event took place in the context of the policy of «de-Stalinization» developed by N.S. Khrushchev, and as a consequence of the relative uncertainty of the relations between the state and Church. An analysis of the methods and means of ideological preparation and control of the host country participants, implemented by the state authorities, primarily by the Council for the Affairs of the Russian Orthodox Church under the USSR Council of Ministers, is important not only for understanding the existing subordinate status of the Russian Orthodox Church in state-church relations. The directives prepared for the clergy, interpreting the issues of the structure and position of the Russian Orthodox Church, freedom of conscience, the significance of religion as a remnant of capitalism in the USSR, testified to the beginning of a new round of theomachist policy. At the same time, the expected but provocative questions for the authorities about the true position of the Russian Orthodox Church in the USSR, as well as persistent statements by foreign guests about the competitiveness of the Orthodox faith in the conditions of the existing state ideology of communism, could serve as a catalyst for the antireligious persecutions launched by the Soviet government in 1958.

Keywords: soviet government, Russian Orthodox Church, the clergy, believers, state-church relations, anti-religious policy, the VI World Festival of Youth and Students.

For citation: Ostroukhova N.V. 2021. The ideological instructions of the Soviet state in relationship to the Russian Orthodox Church and their implementation during the preparation and holding of the VI World Festival of Youth and Students in 1957. Via in tempore. History and political science, 48 (1): 188-197 (in Russian). DOI: 10.52575/2687-0967-2021-48-1-188-197.

В современных условиях углубления в российском обществе духовнонравственного кризиса, обусловленного разрушением семейных устоев и общественных норм морали, выработанных исторически сложившимися в России религиозными конфессиями, сохранение православной культурной традиции как важнейшего ценностного ориентира становится особенно актуальным.

Русская православная церковь (далее - РПЦ) на протяжении советского периода существования российской государственности пережила целый ряд сложных, порою трагических этапов. Одним из них стало очередное ужесточение антирелигиозной политики в СССР в период руководства страной Н.С. Хрущева.

Детальное изучение причин, хода и результатов нового витка агрессивной богоборческой политики руководства СССР по отношению к РПЦ в обозначенный период состоит, прежде всего, в том, чтобы извлечь уроки из негативного исторического опыта, не повторить разрушительных последствий, к которым привела государственная политика насильственного слома мировоззренческой матрицы народа, являвшейся на протяжении многих веков фундаментом строительства русской культуры в целом.

Методологию исследования религиозной политики советского государства в отношении РПЦ в 1953-1964 гг. составляют основополагающие принципы объективности, научности, историзма, системный и ценностный подходы. В процессе подготовки статьи применялись проблемно-хронологический, сравнительно-исторический, герменевтический методы исследования.

В настоящее время внимание исследователей обращено к различным аспектам истории государственно-церковных отношений в СССР второй половины XX века. Используемые советской властью формы, методы и средства реализации конфессиональной политики в отношении РПЦ в 1953-1964 годы, позиции РПЦ на международной арене, а также использование авторитета Церкви во внешнеполитических целях стали предметом исследования таких историков, как Васильева [2004], Марченко [2008], Маслова [2005], Одинцов [2002], Чумаченко [1999], Шкаровский [2010]. Среди работ церковных историков обобщающий характер носят работы Цыпина [1997]. Изучение истории отношений государства и Церкви остро актуализировано в связи с участившимися нападками на РПЦ на постсоветском пространстве. В этой связи представляет интерес изучение проблемы практической реализации идеологических установок советского государства при подго- 
товке и реализации мероприятий VI Всемирного фестиваля молодежи и студентов, проходившего в июле-августе 1957 года. Автор считает, что постановка темы для более углубленного изучения правомерна, поскольку является недостаточно исследованной.

Политика «десталинизации», развернутая Н.С. Хрущевым после ХХ съезда КПСС, включала ряд беспрецедентных в советской истории мероприятий по частичной либерализации общественной жизни. Однако эти меры не коснулись РПЦ как одного из важнейших в стране институтов гражданского общества. И это несмотря на то, что советское руководство проявляло заинтересованность в использовании ресурсов РПЦ во внешнеполитических целях. Прежде всего это касалось использования авторитета и международных организационных возможностей РПЦ в создании единого мирового «фронта» борьбы за мир в условиях «холодной войны» и ожесточенной гонки вооружений, развернувшейся после окончания Второй мировой войны. Не только Русская, но и Зарубежная православная церковь в этот период прилагали значительные усилия по консолидации усилий в миротворческом, пацифистском движении, осуждающем производство, хранение и использование всех видов оружия массового уничтожения, проведение ядерных испытаний, развязывание локальных войн и вооруженных конфликтов.

Например, в составе делегации СССР на состоявшейся в Берлине Чрезвычайной сессии Всемирного Совета Мира, проходившей с 24 по 28 мая 1954 года, участвовал митрополит Крутицкий и Коломенский Николай (Ярушевич), избранный членом Президиума сессии [Митрополит Николай, 1954, с. 17-21]. На повестке дня заседаний в качестве главных стояли два вопроса: «О запрете атомного и термоядерного оружия» и «Безопасность наций» [Чрезвычайная сессия, 1954].

Митрополит Николай был одним из важных участников еще одной международной конференции, проходившей с 19 по 23 июня 1954 года в Стокгольме. Конференция была посвящена ослаблению напряженности в межгосударственных отношениях. Митрополит Николай от имени всех религиозных деятелей, участвовавших в конференции, огласил Обращение к лидерам крупных мировых держав [Обращение, 1954, с. 22].

В своем выступлении митрополит Николай не только осуждал использование атомного и водородного оружия, но и от имени РПЦ он указывал на необходимость увеличения числа встреч малых групп религиозных деятелей в целях укрепления дружбы между церквами и установления контактов в деле защиты мира [Обращение, 1954, с. 22-23].

В предложениях, озвученных митрополитом Николаем, было отмечено, что для реализации цели ослабления международной напряженности, укрепления и поддержания мира в условиях «холодной войны» необходимо расширение международного культурного обмена. В этой связи участники секции по вопросам культуры Международной конференции по ослаблению напряженности в международных отношениях особо подчеркивали первостепенную роль культурного обмена между народами для установления взаимопонимания и доверия, так необходимых для укрепления и поддержания мира [Рекомендации, 1954, с. 27].

Противоречивость политики, проводимой Н.С. Хрущевым, проявлялась, в частности, в том, что международный авторитет РПЦ продолжал активно использоваться руководством СССР в условиях, когда внутри страны государственная машина развертывала широкомасштабные мероприятия очередного витка богоборческой деятельности. Несмотря на крайне сложные внутренние государственно-церковные отношения, помощь политическому руководству СССР со стороны РПЦ в деле борьбы за мир, особенно в межгосударственных культурных обменах, не прекращалась, хотя и осуществлялась в строго заданных советским государством идеологических рамках.

Важной формой развития активного культурного обмена стала интеграция СССР в систему международного туризма и присоединение к международному фестивальному движению молодежи и студентов. В этой связи одним из важнейших событий в рамках развития культурного взаимодействия стало проведение VI Всемирного фестиваля молодежи и студентов, проходившего с 28 июля по 11 августа 1957 года. В фестивале приняли участие 
представители пяти континентов земного шара, делегации 131 страны, и в общей сложности на фестиваль прибыло 34 тысячи гостей. Впервые приняли участие в молодежном фестивале делегации от 17 стран, в том числе Либерии, Ганы, Эфиопии, Новой Зеландии и др. Делегация от США состояла из 141 представителя, что было в пять раз больше, чем на V Bceмирном фестивале, проходившем в Варшаве в 1955 году [Советское зазеркалье, 2007, с. 84]. Символом фестиваля стал рисунок знаменитого французского художника Пабло Пикассо «Голубь мира», лозунгом - слова «За мир и дружбу!» [Лобанов, 2015].

Учитывая степень идеологической нагрузки фестиваля, советское руководство заблаговременно приступило к реализации подготовительных мероприятий к Всемирному молодежному форуму в СССР. Фестиваль был призван нивелировать образ страны «тоталитарного сталинского социализма» в глазах мировой общественности. С точки зрения советского политического руководства, молодежь могла выполнить задачу идеологической рекламы Советского Союза не менее эффективно, чем политики. Наряду с информацией о проводящейся в СССР «десталинизации», важной целью советского коммунистического руководства было «развенчание мифа» о нарушении в Советском Союзе прав граждан на свободу совести, о преследовании верующих и гонений, в частности, на РПЦ.

Для реализации этих задач была составлена специальная программа действий, разосланная во все регионы страны.

Так, в июле 1957 г. из Москвы в адрес всех уполномоченных Совета по делам РПЦ (в том числе уполномоченному по Белгородской области РСФСР) была направлена секретная директива за подписью председателя Совета по делам РПЦ Г.Г. Карпова. В ней содержались инструкции о дополнительной работе, необходимость которой выявилась в рамках мероприятий по подготовке и проведению VI Всемирного фестиваля молодежи и студентов в Москве по линии РПЦ. В совокупности эти мероприятия кратко именовались «Программой взаимодействия» ${ }^{82}$.

Из информации следовало, что в связи с возможным прибытием на фестиваль значительного числа верующей молодежи, которая могла интересоваться вопросами государственно-церковных отношений в СССР, Международный подготовительный комитет включил в программу фестиваля встречи молодых христиан Запада с молодыми христианами СССР для обмена мнениями. Г.Г. Карпов сообщал в директиве, что в этой связи возникла острая необходимость подготовки «специально обученных ответственных лиц» из состава клира, церковных советов, слушателей и преподавателей духовных учебных заведений Советского Союза, ответственных за прием и проведение бесед с представителями зарубежных делегаций.

Следует отметить, что примерный план мероприятий по вопросу подготовки к фестивалю был намечен еще в январе 1957 года на первом совещании председателя Совета по делам РПЦ Г.Г. Карпова с представителями Московской Патриархии и духовенства г. Москвы и Московской области ${ }^{83}$.

От Совета по делам РПЦ группу, ответственную за подготовку и проведение мероприятий в рамках фестиваля, возглавил уполномоченный Васильев, а в Московской Патриархии специально для этой цели созданный подготовительный Комитет возглавил митрополит Николай Крутицкий и Коломенский (Ярушевич) ${ }^{84}$.

Для подготовки выше упоминавшихся «специально обученных ответственных лиц» в Москве были проведены многочисленные инструктивные совещания, на которых были заслушаны доклады и лекции. В частности, информация представителей Подготовительного комитета Борисенкова «О значении фестиваля», лектора ЦК КПСС Юркина «О международном положении», Карпова «О свободе совести и вероисповеданий в СССР», рек-

\footnotetext{
82 Государственный архив Белгородской области (ГАБО). Ф. Р.-140. Оп. 3. № 5. Л. 251-262.

83 Там же. Л. 252.

84 Там же. Л. 253.
} 
тора духовной академии Ружицкого «О вопросах, наиболее часто задаваемых иностранцами, и примерных ответах на них» и другие ${ }^{85}$.

Наиболее «проверенные» с точки зрения надежности студенты Московской духовной академии в составе 30 человек были утверждены в качестве экскурсоводов по ТроицеСергиевой лавре. С данной группой проводились специальные беседы и семинары ректором духовной академии Ружицким и другими работниками патриархии. Специально для данной группы было организовано несколько общих лекций и докладов о международном положении, о достижениях советского народа за 40 лет, об отношениях между церковью и государством, о свободе вероисповедания и свободе совести в СССР и др.

Для зарубежных участников запланированной встречи в Загорске с «действительным положением религии и РПЦ в СССР» была подготовлена специальная справка «Положение религии в СССР, устройство и жизнь Русской православной церкви и ее связи с православными и иностранными церквами и объединениями», которая затем была использована в докладе Ружицкого на встрече христиан, переведена на английский и французский языки и роздана иностранным делегатам ${ }^{86}$.

Вместе с тем в ходе фестиваля намеченная «Программа взаимодействия» неоднократно подлежала корректировке. Так, христиане Великобритании неожиданно поставили вопрос о необходимости проведения специального собеседования молодых зарубежных христиан с молодыми христианами СССР. Представители СССР в составе молодых священнослужителей, слушателей академий и семинарий и нескольких мирянок, выбранных для участия в собеседовании, были быстро и «основательно подготовлены» для такого «собеседования». Лично Председателем Совета по делам РПЦ Карповым и его первым заместителем Белышевым для них было прочитано несколько специальных лекций с освещением вопроса о свободе совести в СССР, устройстве, положении и деятельности РПЦ в СССР. Кроме того, Московская Патриархия подготовила и разослала по церквам краткую канонико-статистическую справку для ознакомления всех лиц, работающих с иностранцами, с целью унификации ответов о РПЦ ${ }^{87}$.

Ожидания советского руководства относительно проявления зарубежной молодежью интереса к положению религии и Церкви в Советском Союзе оправдались. В дни фестиваля только московские церкви посетило свыше шести тысяч человек ${ }^{88}$.

Из секретной директивы Г.Г. Карпова, разосланной из Москвы в регионы, следовало, что представители иностранных делегаций интересовались не только вопросами истории и архитектуры конкретных церквей, положением, структурой и деятельностью РПЦ, но и взаимоотношением верующих с государственной властью, перспективами развития РПЦ, вопросами религиозного воспитания в СССР, идеологическим соотношением религии и коммунизма и др. ${ }^{89}$ Итогом собеседования были как положительные, так и отрицательные отзывы со стороны иностранных делегаций. Так, отдельные зарубежные гости выражали недоверие к действительному положению РПЦ, сомневались в том, что церкви являются действующими, а не являются национализированными музеями ${ }^{90}$. Однако были и положительные результаты.

Так, в запланированной встрече, состоявшейся 31 июля 1957 года в ТроицеСергиевой лавре (г. Загорск), приняли участие 750 молодых христиан из 17 стран, в том числе 230 представителей делегации Великобритании. От христиан Советского Союза присутствовало 700 представителей, в том числе более 600 - от РПЦ. Гости познакомились с историей Лавры, осмотрели соборы, помещения семинарии, академии, ознакоми-

\footnotetext{
85 Там же.

86 Там же. Л. 254

${ }^{87}$ Там же. Л. 254-255.

${ }^{88}$ Там же. Л. 255.

89 Там же. Л. 255-256.

90 Там же. Л. 256.
} 
лись с материалами выставки «О жизни Русской Православной Церкви» ${ }^{91}$. По информации Г.Г. Карпова посещение Лавры оказало значительное позитивное влияние, способствовало изменению взглядов о положении церкви в СССР в лучшую сторону у представителей делегаций Бразилии, Бельгии, Швейцарии и Испании 92 .

По инициативе делегации Великобритании 3 августа состоялась новая встреча молодых христиан в составе 150 человек, в том числе представителей от христианских церквей Италии, Франции, ФРГ, ГДР, Чехословакии, Китая, Швеции, Австрии, Дании. Среди них наиболее значительное по численности представительство (по 30 человек) имели делегации Великобритании и СССР. После секционного обсуждения вопросов о месте христиан в государстве и обязанностей христиан в деле защиты мира все собрались на пленарное заседание, где была отмечена положительная роль и целесообразность подобного рода встреч, в том числе для подготовки Всемирной конференции молодых христиан 93 .

Всего в дни фестиваля Троице-Сергиеву лавру посетило более 30 групп иностранных делегаций, включавших около 400 человек. Молодые люди задавали самые разные, в том числе весьма острые политические и идеологические вопросы. Например, студентов и журналистов из ФРГ интересовало, не заменит ли коммунизм в конечном итоге религию, и почему РПЦ не противопоставляет коммунистическому учению и его пропаганде организованную миссионерскую деятельность ${ }^{94}$.

Одна из групп американцев интересовалась, может ли священник с амвона критиковать правительственные действия; и как чувствуют себя духовенство и верующие в атеистическом государстве ${ }^{95}$.

Активную работу на фестивале вели представители Московской Патриархии. Так, в период с 15 июля по 9 августа 1957 года Московскую Патриархию посетило 20 групп и отдельных лиц - участников молодежного форума.

Митрополит Николай принял делегацию общественных и религиозных деятелей из США во главе с исполнительным секретарем $\mathrm{OOH}$ и межправительственных связей Г. Боссом. Состоялись визиты президента японского религиозного общества «Конкокио» (Сопроцветание народов) Тосио Мияке; пастора Форбека из Норвегии; профессора К. Фассбиндер из ФРГ; пастора Ф. Кларк из Великобритании, Генерального секретаря китайского национального комитета ИМКА Цзянь-Вань-Ханя.

Митрополит Николай принял также членов патриаршего совета Антиохийской церкви профессоров Л. Дирани, И. Хури; ассистента экуменистического семинара университета в Марбурге (ФРГ), д-ра философии Г. Канус-Креде; директора журнала «Африканская действительность» г-на Дьона (Сенегал); председателя делегации Кипра С. Маркидеса. В Московской Патриархии побывали группы участников фестиваля из Канады, Голландии, ФРГ, международного общества «Друзей примирения» во главе с вицепрезидентом Жаном Госсом (Франция) и других ${ }^{96}$.

В уже упоминавшейся выше директиве Г.Г. Карпова какие-либо замечания к действиям и высказываниям участников молодежного форума от Советского Союза отсутствовали. Более того, подчеркивалась признанная представителями зарубежных делегаций положительная роль подобных встреч и проводимых диспутов в деле укрепления дружественных взаимосвязей и борьбы за мир ${ }^{97}$.

В ходе работы Фестиваля активная советская идеологическая работа шла по всем направлениям.

\footnotetext{
91 Там же. Л. 257.

92 Там же. Л. 257-258.

93 Там же. Л. 258-259.

94 Там же. Л. 259.

95 Там же. Л. 260.

96 Там же. Л. 261.

97 Там же. Л. 262.
} 
Например, информация о положении РПЦ в СССР и ее взаимоотношениях с властью содержалась в «Кратких сведениях о Русской православной церкви на 1 апреля 1957 года». «Краткие сведения» были составлены Московской Патриархией и разосланы ею всему составу патриархальных архиереев как подсобный справочный материал при беседах с иностранными гостями ${ }^{98}$.

Очевидно, что данный документ содержал официальную, исключительно позитивную, а следовательно, искаженную трактовку действительного положения РПЦ в СССР. В нем были указаны только два основополагающих нормативных акта, которые определяли положение религии в Советском государстве - Декрет Советского Правительства от 23 января 1918 года «Об отделении Церкви от Государства и школы от Церкви» и Конституция СССР 1936 г. (ст. 124). Отсутствовали сведения об утвержденном постановлением СНК СССР от 28 января 1944 года за № 162 «Положении об управлении Русской православной церкви», которое качественно улучшало положение церкви в СССР [Постановление СНК СССР, 28.01.1944 г.]. Особое внимание уделялось трактовке свободы совести в СССР. Подчеркивалось, что государство гарантирует религиозным объединениям полную свободу самоуправления, предъявляя к ним единственное требование - не нарушать законов страны ${ }^{99}$. В качестве связующего звена между религиозными объединениями и правительством Советского Союза, а также местными органами власти указывались Совет по делам РПЦ и Совет по делам религиозных культов при Совете Министров СССР, которые должны были способствовать реализации гражданами СССР свободы совести, провозглашенной конституцией ${ }^{100}$. Исходя из официальной трактовки, РПЦ в своей деятельности не испытывала никакого притеснения и вмешательства в свою внутреннюю жизнь со стороны государства ${ }^{101}$. В данном документе представлена картина безоблачного мирного взаимодействия Церкви и государства без всякого явного или скрытого давления со стороны последнего на РПЦ. Эта картина была далека от реальной жизни, но духовенство должно было строго придерживаться предписанных им идеологических установок, особенно в случае возможных встреч с иностранными гражданами, которые проявляли интерес к действительному положению Церкви в СССР.

Для реализации вышеуказанных установок Советом по делам РПЦ 5 июля 1957 года было направлено в адрес уполномоченных Совета по делам РПЦ на местах секретное инструктивное письмо, так называемая «Справка о церкви в СССР». Ее рекомендовано было обязательно использовать всем, прежде всего - духовенству, в беседах с иностранцами в случае обращения последних с вопросами о положении церкви в СССР и взаимоотношениях РПЦ с государством ${ }^{102}$. По сравнению с «Краткими сведениями о Русской православной церкви на 1 апреля 1957 года» в «Справке о церкви в СССР» гораздо большее внимание уделялось разъяснению вопросов о свободе совести в СССР и о сущности отделения Церкви от государства и школы от Церкви ${ }^{103}$.

Обращаясь к истории, в том числе к характеристике положения РПЦ в царской России, автор данной справки утверждал, что русский народ никогда не был глубоко верующим, а принадлежал к православию по необходимости. Иначе, по мысли автора, вряд ли так быстро большинство советских людей отошли от религии и стали атеистами 104.

Кроме того, по мнению составителя справки, в Советском Союзе отсутствовали любые основания для утверждения о притеснениях и гонениях на РПЦ и верующих, по-

\footnotetext{
98 Там же. Л. 46.

99 Там же. Л. 47.

100 Там же. Л. 48.

101 Там же. Л. 49.

102 Там же. Л. 65-119.

103 Там же. Л. 73-81.

104 Там же. Л. 72.
} 
скольку религия в СССР, являясь пережитком капитализма в сознании людей, находилась в процессе отмирания ${ }^{105}$.

Таким образом, по состоянию на 1957 год РПЦ еще удавалось, хотя и с большим трудом, отстаивать свое вновь неопределенное после смерти И.В. Сталина (вследствие политики «десталинизации», развернутой Н.С. Хрущевым) положение в рамках такого официально атеистического государства, как СССР. Исходя из анализа состава представителей зарубежных делегаций VI Всемирного фестиваля молодежи и студентов, характера и тематики задаваемых рядовому духовенству и руководству РПЦ в лице митрополита Николая вопросов, положение РПЦ для иностранных граждан служило критерием для определения действительного наличия в Советском Союзе гражданских свобод, записанных в советской Конституции 1936 г. Для представителей духовенства СССР не было неожиданным появление вопросов о взаимоотношении государства и Церкви, соотношении религии и коммунизма. Ответственные лица были идеологически подготовлены к ответам на такие «острые» вопросы.

В стремительно меняющейся в СССР после смерти И.В. Сталина обстановке Московская Патриархия, пытаясь не допустить обострения взаимоотношений между церковью и политическим руководством страны, вынужденно подчинялась идеологическим установкам и требованиям советского руководства. Это, в свою очередь, углубляло раскол в православии в целом, поскольку делало невозможным примирение РПЦ с Русской Зарубежной православной церковью и ее многочисленными приходами.

С другой стороны, и коммунистическое руководство СССР, руководимое Н.С. Хрущевым, старалось дискредитировать РПЦ в глазах граждан, особенно молодежи. И поэтому любое проявление положительного потенциала РПЦ как внутри страны - в вопросах нравственности и культуры, так и в международной деятельности РПЦ по объединению усилий верующих в борьбе за сохранения мира, использовалось, но в идеологической антирелигиозной пропаганде квалифицировалось как «приспособленчество».

Вероятно, настойчивая и весьма острая постановка иностранными делегатами вопросов о конкуренции православия и коммунизма могла стать одним из катализаторов масштабной богоборческой политики на государственном уровне, которая была инициирована Н.С. Хрущевым и развернута в полном объеме, начиная с 1958 года.

\section{Список литературы}

1. Васильева О.Ю. 2004. Русская Православная Церковь и Второй Ватиканский Собор. Москва, Лепта, 380 с.

2. Лобанов К. 2015. Исторические хроники. VI Всемирный фестиваль молодежи и студентов. URL: http://vkomsomole.ru/articles/854---vi-----(Дата обращения 19.01.2019).

3. Митрополит Николай. 1954. На Чрезвычайной сессии Всемирного Совета Мира. Журнал Московской Патриархии, 7: 17-21. http://jmp.ru/ymarh4354y.php?уo=54\&mo=07 (Дата обращения 19.01.2019).

4. Марченко А.Н. 2008. Хрущевская церковная реформа и ее влияние на внутрицерковную жизнь по материалам уральского региона: 1958-1964 гг. Дис. ... докт. ист. наук. Москва, 392 с.

5. Маслова И.И. 2005. Эволюция вероисповедной политики советского государства и деятельности Русской православной церкви (1953-1991). Автореф. дис. ... докт. ист. наук. Москва, $46 \mathrm{c}$.

6. Обращение к верующим всех религий мира. 1954. Журнал Московской Патриархии, 7: 22-23. URL: http://jmp.ru/ymarh4354y.php?уo=54\&mo=07 (Дата обращения 19.01.2019).

7. Одинцов М.И. 2002. Русская православная церковь в XX веке: история, взаимоотношения с государством и обществом. Москва, РОИР, 312 с. 
8. Постановление СНК СССР «Положение об управлении Русской православной церкви» № 162 от 28.01.1944 г. В кн.: Русская православная церковь в годы Великой Отечественной войны 1941-1945 гг. 2009. Сборник документов. Сост. О.Ю. Васильева, И.И. Кудрявцева, Л.А. Лыкова. Москва, Издательство Крутицкого подворья, Общество любителей церковной истории, 271-278.

9. Рекомендации международной конференции по ослаблению напряжения в международных отношениях. 1954. Журнал Московской Патриархии, 7: 25-29. URL: http://jmp.ru/ymarh4354y.php?yo=54\&mo=07 (Дата обращения 19.01.2019).

10. Советское зазеркалье. Иностранный туризм в СССР в 1930-1980-е годы: учебное пособие. 2007. Сост. Багдасарян В.Э., Орлов И.Б., Мазин К.А., Федулин А.А., Шнайдген Й.Й. Москва, ФОРУМ, 256 с.

11. Цыпин В. 1997. История Русской церкви. 1917-1997. Москва, Издательство СпасскоПреображенского Валаамского монастыря, 831.

12. Чрезвычайная сессия Всемирного Совета Мира. (ТАСС). 1954. Сталинец, 63 (2754). 28 мая. URL: http://musey29.ru/wp-content/uploads/2018/12/63-28-maya-1954-goda.pdf (Дата обращения 17.02.2019).

13. Чумаченко Т.А. 2014. Государство и Русская православная церковь в 1958-1964 годах: новая политическая война с религией, церковью, верующими. Вестник Челябинского государственного университета, 19 (348). Право, 39: 83. URL: https://cyberleninka.ru/article/v/gosudarstvo-i-russkaya-pravoslavnaya-tserkov-v-1958-1964-godahnovaya-politicheskaya-voyna-s-religiey-tserkovyu-i-veruyuschimi (Дата обращения 17.02.2019).

14. Чумаченко Т.А. 1999. Государство, православная церковь, верующие, 1941-1961 гг. Москва: АИРО-ХХ, 247 с.

15. Шкаровский М.В. 2018. Антирелигиозные гонения 1958-1964 гг. в Ленинградской епархии и противостояние им митрополита Никодима (Ротова). Вестник исторического общества, 2: 19-33. DOI: 10.24411/2587-8425-2018-10012 URL: https://cyberleninka.ru/article/n/antireligioznyegoneniya-1958-1964-gg-v-leningradskoy-eparhii-i-protivostoyanie-im-mitropolita-nikodima-rotova (Дата обращения 19.01.2019).

16. Шкаровский М.В. 2010. Русская Православная Церковь в XX веке. Москва: Вече, Лепта, 480 c.

17. Шкаровский М.В. 1999. Русская Православная Церковь при Сталине и Хрущеве (государственно-церковные отношения в СССР в 1939-1964 годах). - Москва: Крутицкое Патриаршее подворье, Общество любителей церковной истории, 400 с.

\section{References}

1. Vasil'eva O.Yu. 2004. Russkaya pravoslavnaya tserkov' i Vtoroy Vatikanskiy Sobor [Russian Orthodox Church and the Second Vatican Council]. Moscow, Publ. Lepta, 380 p. (in Russian).

2. Lobanov K. 2015. Istoricheskie hroniki. VI Vsemirnyj festival' molodezhi i studentov [Historical chronicles. VI World Festival of Youth and Students]. Available at: http://vkomsomole.ru/articles/854---vi-----(accessed: 19 January 2019) (in Russian).

3. Mitropolit Nikolaj. 1954. Na Chrezvychajnoj sessii Vsemirnogo Soveta Mira [At the Extraordinary Session of the World Peace Council]. Zhurnal Moskovskoj Patriarhii, 7: 17-21. Available at: http://jmp.ru/ymarh4354y.php?yo=54\&mo=07 (accessed: 19 January 2019) (in Russian).

4. Marchenko A.N. 2008. Khrushchevskaya tserkovnaya reforma i ee vliyanie na vnutritserkovnuyu zhizn' po materialam ural'skogo regiona: $1958-1964 \mathrm{gg}$. [Khrushchev's church reform and its impact on church life based on materials from the Urals region: 1958-1964]. Dis. ... dokt. ist. nauk. Moscow, 392 p. (in Russian).

5. Maslova I.I. 2005. Evolyutsiya veroispovednoy politiki sovetskogo gosudarstva i deyatel'nosti Russkoy pravoslavnoy tserkvi (1953-1991) [The evolution of the religious policy of the Soviet state and the activities of the Russian Orthodox Church (1953-1991)]. Abstract. dis. ... dokt. ist. nauk. Moscow, 46 p. (in Russian).

6. Obrashchenie $\mathrm{k}$ veruyushchim vsekh religij mira. 1954 [An appeal to believers of all religions of the world]. Zhurnal Moskovskoj Patriarhii, 7: 22-23. Available at: http://jmp.ru/ymarh4354y.php?yo=54\&mo=07 (accessed: 19 January 2019) (in Russian). 
7. Odintsov M.I. 2002. Russkaya pravoslavnaya tserkov' $\mathrm{v}$ XX veke: istoriya, vzaimootnosheniya s gosudarstvom i obshchestvom [The Russian Orthodox Church in the twentieth century: history, relations with the state and society]. Moscow, Publ. RARR, 312 p. (in Russian).

8. The resolution of the Council of People's Commissars of the USSR «Regulations on the management of the Russian Orthodox Church» No. 162 of 01.28.1944. In: Russian Orthodox Church during the Great Patriotic War of 1941-1945. 2009. Collection of documents. Comp. O.Yu. Vasilyeva, I.I. Kudryavtseva, L.A. Lykova. Moscow, Publishing House of the Krutitsky Compound, Society of Church History Fans, 271-278 (in Russian).

9. Rekomendacii mezhdunarodnoj konferencii po oslableniyu napryazheniya $\mathrm{v}$ mezhdunarodnyh otnosheniyah [Recommendations of the international conference on easing tensions in international relations] ZHurnal Moskovskoj Patriarhii, 7: 25-29. Available at: http://jmp.ru/ymarh4354y.php?yo=54\&mo=07 (accessed: 19 January 2019) (in Russian).

10. Sovetskoe zazerkal'e. Inostrannyj turizm v SSSR v 1930-1980: uchebnoe posobie. 2007 [Soviet through the looking glass. Foreign tourism in the USSR in the 1930-1980s]. Comp. Bagdasaryan V.E., Orlov I.B., Mazin K.A., Fedulin A.A., SHnajdgen. J.J. Moscow, Publ. FORUM, 256 p. (in Russian).

11. Tsypin V. 1997. Istoriya Russkoy tserkvi. 1917-1997 [The History of the Russian Church. 1917-1997]. Moscow, Spassko-Preobrazhensky Valaam Monastery Publishing House, 831 p. (in Russian).

12. Chrezvychajnaya sessiya Vsemirnogo Soveta Mira [Extraordinary session of the World Peace Council] (TASS) 1954. Stalinec, 63 (2754). 28 maya. Available at: http://musey29.ru/wpcontent/uploads/2018/12/63-28-maya-1954-goda.pdf (accessed: 17 February 2019) (in Russian).

13. Chumachenko T.A. 2014. Gosudarstvo i Russkaya Pravoslavnaya Tserkov' v 1958-1964 godakh: novaya politicheskaya voyna s religiey, tserkov'yu, veruyushchimi. Vestnik Chelyabinskogo gosudarstvennogo universiteta, 19 (348). Pravo, 39: 83 [The State and the Russian Orthodox Church in 1958-1964: a new political war with religion, the church, and believers. Bulletin of Chelyabinsk State University, 19 (348). Right, 39: 83]. Available at: https://cyberleninka.ru/article/v/gosudarstvo-irusskaya-pravoslavnaya-tserkov-v-1958-1964-godah-novaya-politicheskaya-voyna-s-religiey-tserkovyui-veruyuschimi (accessed: 17 February 2019) (in Russian).

14. Chumachenko T.A. 1999. Gosudarstvo, pravoslavnaya tserkov', veruyushchie, 1941-1961 gg. [State, Orthodox Church, believers, 1941-1961]. Moscow, Publ. AIRO-XX, 247 p. (in Russian).

15. Shkarovskiy M.V. 2018. Antireligioznye goneniya 1958-1964 gg. v Leningradskoy eparkhii i protivostoyanie im mitropolita Nikodima (Rotova). Vestnik istoricheskogo obshchestva [Anti-religious persecution of 1958-1964 in the Leningrad diocese and the confrontation by Metropolitan Nicodemus (Rotov). Bulletin of a historical society], 2: 19-33. DOI: 10.24411/2587-8425-2018-10012 Available at: https://cyberleninka.ru/article/n/antireligioznye-goneniya-1958-1964-gg-v-leningradskoy-eparhii-iprotivostoyanie-im-mitropolita-nikodima-rotova (accessed: 19 January 2019) (in Russian).

16. Church in Shkarovskiy M.V. 2010. Russkaya pravoslavnaya tserkov' v XX veke [Russian Orthodox the twentieth century]. Moscow, Publ. Veche, Lepta, 480 p. (in Russian).

17. Shkarovskiy M.V. 1999. Russkaya pravoslavnaya tserkov' pri Staline i Khrushcheve (gosudarstvenno-tserkovnye otnosheniya v SSSR v 1939-1964 godakh) [The Russian Orthodox Church under Stalin and Khrushchev (state-church relations in the USSR in 1939-1964)]. Moscow, Publ. Krutitsky Patriarchal Compound, Society of Church History Fans, 400 p. (in Russian).

\section{ИНФОРМАЦИЯ ОБ АВТОРЕ}

Остроухова Наталья Валерьевна, аспирант кафедры российской истории и документоведения Белгородского государственного национального исследовательского университета, г. Белгород, Россия

\section{INFORMATION ABOUT THE AUTHOR}

Natalya V. Ostroukhova, postgraduate student of the Department of Russian history and pre-study Belgorod State National Research University, Belgorod, Russia 